\title{
Landslide Susceptibility Mapping of Highway Slopes, Using Stability Analyses and GIS Methods
}

\author{
A.M.L. Craig, O. Augusto Filho
}

\begin{abstract}
The study presented in this paper aims to map landslide susceptibility on highway slopes and adjacent areas, using an approach based on stability analysis with deterministic methods considering semi-regional and detail work scales. The infinite slope method in a Geographic Information System (GIS) environment and a 1:10,000 scale topographic base (elevation intervals of $5 \mathrm{~m}$ ) were used in the stability analysis at the semi-regional scale. Geological-geotechnical sections surveyed in the field with measuring tape and inclinometer (1:100 scale with $0.5 \mathrm{~m}$ vertical slope intervals) and the Bishop Simplified method were used in the detail scale. The geological-geotechnical materials present in the studied area are residual soils (sandstones, basalt and diabase), alluvial deposits and landfills. The slopes and marginal areas of the highway more susceptible to landslides were mapped based on quantitative models of analysis, reducing the subjectivity of the mapping. Limitations of the infinite slope method related to its physical-mathematical model were identified and analyzed. The approach used was efficient even considering the limitations of the infinite slope analysis method and the representativeness of the geomechanical parameters used in the stability analyses.
\end{abstract}

Keywords: Bishop Simplified, geological-geotechnical sections, infinite slope, residual soils, safety factor, slope susceptibility.

\section{Introduction}

During the execution of linear works a diversity of geological-geotechnical materials can be exposed, such as rock units and associated soils, as well as surface and underground water dynamics, which in turn, respond in different manners to the demands imposed by the system. In the case of highways, there are problems associated with the stability of the slopes and embankments.

Several studies have addressed this theme given its social, economic and environmental importance in highway management. Data from the Brazilian National Department of Transport Infrastructure shows that, only in 2011, about $\mathrm{R} \$ 150$ million were invested on the recovery of federal highways affected by landslides and erosion processes (DNIT, 2014).

The most recent studies dealing with landslide susceptibility mapping have used the combination of deterministic stability analysis models, such as the infinite slope method, with hydrological models in a Geographic Information System (GIS) environment. Following this research line, stand out the models SHALSTAB - Shallow Slope Stability Model (Montgomery \& Dietrich, 1994); dSLAM Distributed Slope Stability Model (Wu \& Sidle, 1995; Dhakal \& Sidle, 2003); SINMAP -Stability Index Mapping (Pack et al., 1998; Pack et al., 2005) and TRIGRS -Transient Rainfall Infiltration and Grid-Based Regional SlopeStability Model (Savage et al., 2004; Baum et al., 2002; Baum et al., 2008).
Some examples of the application of SHALSTAB and TRIGRS models are the studies of Ramos et al. (2002), Vieira (2007), Park et al. (2013), Rosniecek \& Imai (2013) and Gioia et al. (2014). Wu \& Abdel-Latif (2000), Augusto Filho (2006) and Silveira et al. (2012) used the infinite slope method in the elaboration of landslide susceptibility maps.

In this context, this paper proposes a landslide susceptibility mapping of the highway slopes and adjacent areas using an approach based on stability analyses with deterministic methods and considering semi-regional and detail work scales.

The infinite slope method in a GIS environment and a 1: 10,000 scale topographic base (elevation intervals of $5 \mathrm{~m}$ ) were used in the stability analyses at the semi-regional scale. The Bishop Simplified method (available in the Slope/W module of the GeoStudio software) and geological-geotechnical sections surveyed in the field (1:100 scale with $0.5 \mathrm{~m}$ vertical slope intervals) were used in the detail scale.

The use of two simultaneous scales of analysis can be considered one of the differentials of the current study when compared to previous studies of landslide susceptibility mapping based on quantitative models. Another relevant aspect regards the identification and discussion of the limitations of the infinite slope method related to its physical-mathematical model. This method tends to produce anomalous results with the increase of safety factor $(S F)$ rather than its reduction for failure surfaces with slopes greater than $60^{\circ}$ and depths less than $1 \mathrm{~m}$.

Ayla Margie de Leão Craig, M.Sc., Belo Horizonte, MG, Brazil. e-mail: aylaleao@ gmail.com.

Oswaldo Augusto Filho, Ph.D., Associate Professor, Departamento de Geotecnia, Universidade de São Paulo, São Carlos, SP, Brazil. e-mail: oafilho@ sc.usp.br.

Submitted on March 26, 2019; Final Acceptance on January 29, 2020; Discussion open until August 31, 2020.

DOI: $10.28927 /$ SR.431071 
The infinite slope method, developed by Skempton \& DeLory (1957), assumes that the depth of failure is much less than the total extent of the slope and that the balance between the resistive and sliding forces on a single slope slice is sufficient to represent the level of stability of the entire slope. This simplification makes the method quite malleable for its application in various situations and presents a good compatibility with computer programs, especially those involving GIS (Ahrendt, 2005). The calculation of the $S F$ in the infinite slope method is performed through the Eq. 1 below as proposed by Massad (2003).

$$
S F=\frac{\mathbf{c}^{\prime}+\left(\gamma_{\text {nat }} \times z \cos ^{2} i-\mathbf{u}\right) \tan \Phi^{\prime}}{\gamma_{\text {nat }} \times z \sin i \cos i}
$$

in which $S F=$ safety factor; $\mathbf{c}^{\prime}=$ effective cohesion; $\gamma_{\text {nat }}=$ natural unit weight; $\phi$ ': effective friction angle; $z=$ depth of failure plane; $i=$ slope angle; $\mathbf{u}=$ pore water pressure.

Bishop's method of analysis is a modification of the Fellenius method taking into account the balance of moments (resistant and acting) and the balance of forces acting on each coverslip (Fiori \& Carmignani, 2009; Gaioto, 1992). The Bishop Simplified method considers the balance of forces and moments, initially proposed by Bishop, neglecting the lateral forces between the slices. In other words, the Simplified Bishop Method admits a circular failure surface and considers that the forces on the sides of the slices are horizontal, disregarding the tangential forces between them. This simplification results in a $1 \%$ error on the exact calculation (Abramson et al., 2002).
As it can be seen in Eqs. 2, 3 and 4 below, in the Simplified Bishop method the safety factor is obtained by an interative process.

$$
S F=\frac{\sum\left[b \times \mathbf{c}^{\prime}+(\mathbf{W}-\mathbf{u} \times b) \tan \Phi^{\prime}\right] \times \frac{1}{\mathbf{M}(\alpha)}}{\sum \mathbf{W} \sin \alpha}
$$

$b=l \cos \alpha$

$$
\mathbf{M}(\alpha)=\cos \alpha\left(1+\frac{\tan \Phi^{\prime} \tan \alpha}{S F}\right)
$$

in which $S F=$ safety factor; $b=$ slice thickness; $\mathbf{W}=$ slice weight; $\mathbf{c}^{\prime}$ and $\phi^{\prime}=$ effective cohesion and friction angle at the base of the slice center; $\mathbf{u}=$ pore water pressure at the base of the slice center; $1=$ length of slice base.

\section{Study Area}

The study area covers a range of $500 \mathrm{~m}$ width on both sides of Luís Augusto de Oliveira highway (SP-215), between kilometers 170 to 192.2 (geographic coordinates

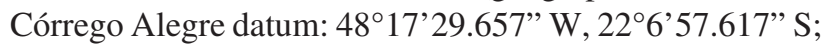

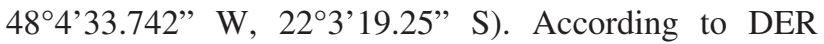
(2015), in 2014 the Average Daily Volume (ADV) of traffic on this highway reached 3,259 vehicles per day.

The studied section of the SP-215 highway crosses the municipalities of São Carlos, Ribeirão Bonito and Dourado, located in the center-west of the state of São Paulo, Brazil. The 1: 10,000 digital cartographic base was assembled on seven A3 sheets for printing (Fig. 1).

These areas are geologically composed of aeolian and fluvial sandstones (Botucatu and Adamantina formations,

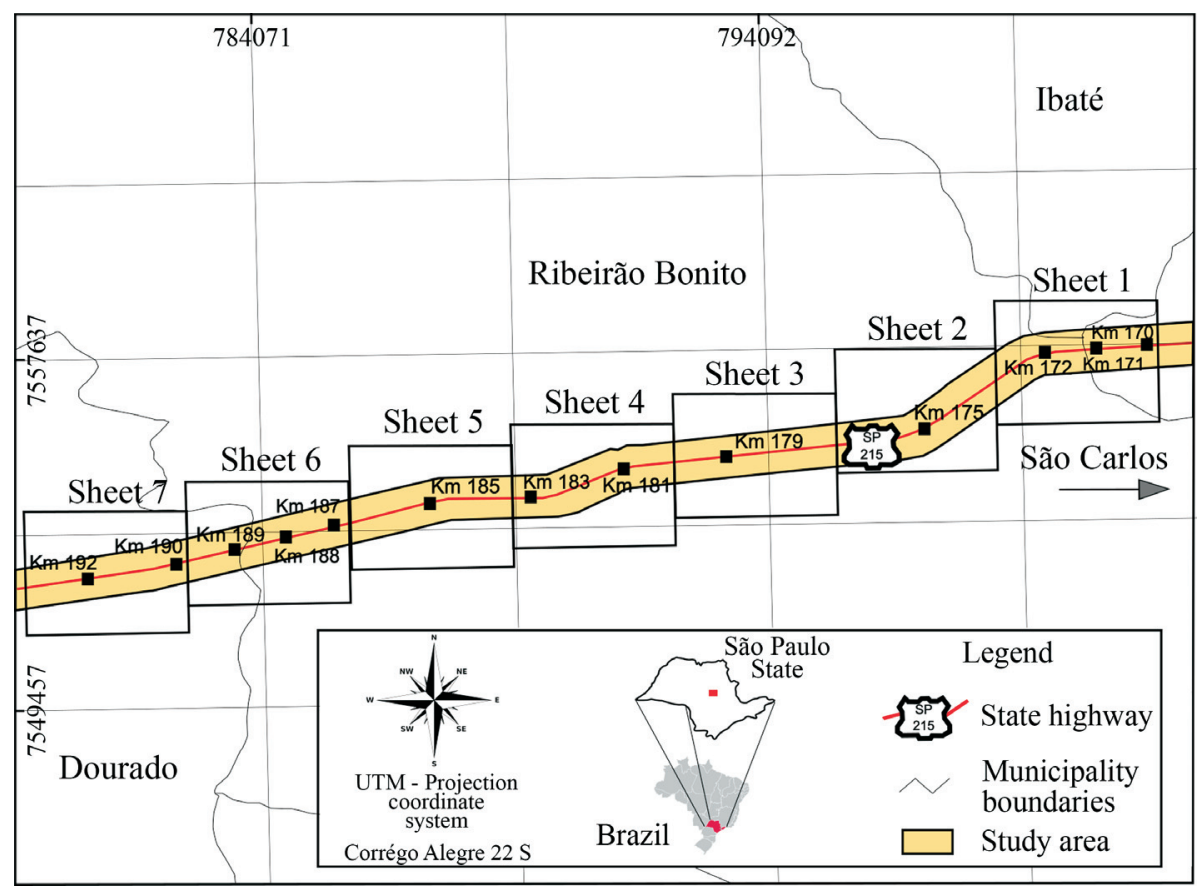

Figure 1 - Study area. 
respectively), basalt and diabase rocks (Serra Geral Formation), and their respective residual soils, that together comprise the register of the Paraná Basin (Devonian-Cretaceous ages) in the State of São Paulo (IPT, 1981a). Subordinately, detrital slope deposits (colluvium) and alluvial deposits can occur in larger drainages. Geomorphologically the area mostly comprises hills, basaltic plateaus and escarpments (IPT, 1981b).

The rainy season runs from October to March, with the rainiest quarter from December to February. The driest period is from April to September, with the driest quarter between June and August.

Although the studied region does not present the same levels of natural susceptibility to the occurrence of landslides as the crystalline mountainous regions, these processes have occurred with a certain frequency, mainly in the highway cuts (Fig. 2).

\section{Materials and Methods}

The main materials and software used in the study were topographic maps at 1:10,000 scale, aerial images from Google Earth Pro and field survey equipment (geological hammer, measuring tape, inclinometer and compass), Arcmap (2010), Geoslope (2012) and Office (2010).

Initially, the subject of the research was defined, a bibliographic review was made and also the study area was chosen. Then, the research was developed according to the four major steps outlined below: Inventory; Landslide susceptibility mapping at 1:10,000 scale; Slope stability analyses at detail scale; and Synthesis.

\subsection{Inventory}

At this stage, the main geological and geotechnical information of interest for the study were collected and organized, and the digital cartographic base, the Digital Terrain Model (DTM) and the thematic maps necessary for the landslide susceptibility mapping of the surroundings and slopes of the highway at 1: 10,000 scale were produced. All maps produced in this step were elaborated using the GIS Arcmap/Arcgis spatial analysis tools.

The digital cartographic base at 1:10,000 scale included the topographical information (elevations contours every $5 \mathrm{~m}$, elevation points, streams, highway cuts and landfills) and a mosaic of aerial images from Google Earth Pro. The thematic maps produced were: Shading, Hypsometric; Slope; and Geological Materials.

The DTM was produced with the top to raster command of the 3D Analyst Tools module. This tool performs a hydrologically correct interpolation of a surface starting from the input data related to the elevation contours, elevation points, streams, and boundaries of the digital cartographic base. A cell size of $2.5 \mathrm{~m}$ was defined as the

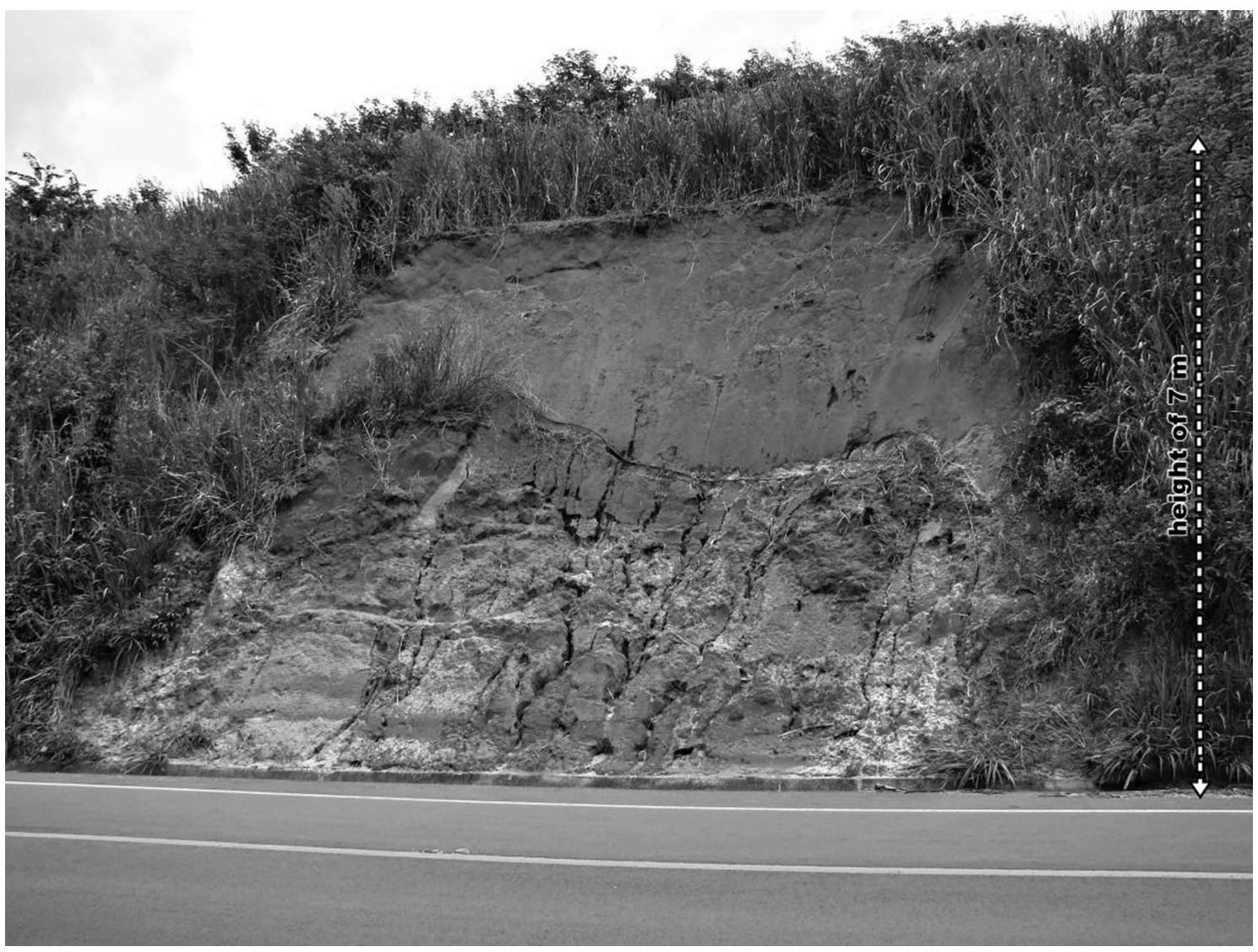

Figure 2 - Highway cut with shallow landslide in sandstone residual soil (Botucatu Formation). 
interpolation grid, which is $50 \%$ lower than the maximum permissible cartographic error at $1: 10,000$ scale $(0.5 \mathrm{~mm}$ or $5 \mathrm{~m})$.

The filter and the fill tools were applied to obtain the final hydrologically correct interpolated raster surface. The final DTM was qualitatively evaluated to ensure that it provided a realistic representation of the topographic surface. The qualitative evaluation created contours from the new surface with Contour tool and compared them to the input contour data.

These procedures are important because the accuracy of the shading, hypsometric and slope maps and of the landslide susceptibility mapping at 1:10,000 scale is largely associated with the quality of the DTM.

The map of geological materials was produced based on preexisting mappings and field surveys along the studied section of the highway.

\subsection{Landslide susceptibility mapping at scale $1: 10,000$}

The whole set of information obtained in the inventory stage allowed the accomplishment of a preliminary geological-geotechnical characterization of the study area and to carry out the landslide susceptibility mapping at 1:10,000 scale using the infinite slope method. This approach enabled the definition of landslide susceptibility by calculating the safety factor $(S F)$ in all the cells of the terrain according to the characteristics of each one.
The safety factors $(S F)$ were calculated using the infinite slope method (Eq. 1) and applying the raster calculator tool of the GIS considering a $2.5 \mathrm{~m}$ grid (same as the DTM). The operation was done using matrices with the data of the soil geomechanical parameters, slope, groundwater conditions and the depth of the failure surface (Fig. 3).

Three main scenarios were simulated taking into account the groundwater conditions and the failure plane. The objective of these simulations was to obtain the best fit between the model of landslide susceptibility mapping and the data collected in the field surveys.

Additional simulations were performed aiming to understand some anomalous results obtained related to limitations of the infinite slope stability analysis method not mentioned in previous studies. The conditions of $S F v s$. slope angle and failure surface depth, effective cohesion, friction angle and water level above the failure surface were simulated, taking as an example the geomechanical parameters of Botucatu Formation.

Due to limitations, infinite slope and the topography detail for 1:10,000 scale used for landslide susceptibility mapping, a modeling for the highway cuts and landfills was necessary to be performed separately.

In order to observe the most critical situation of analysis, the minimum values of cohesion and friction angle and maximum values of unit weight were adopted based on data found in the literature. The $S F$ values obtained for each

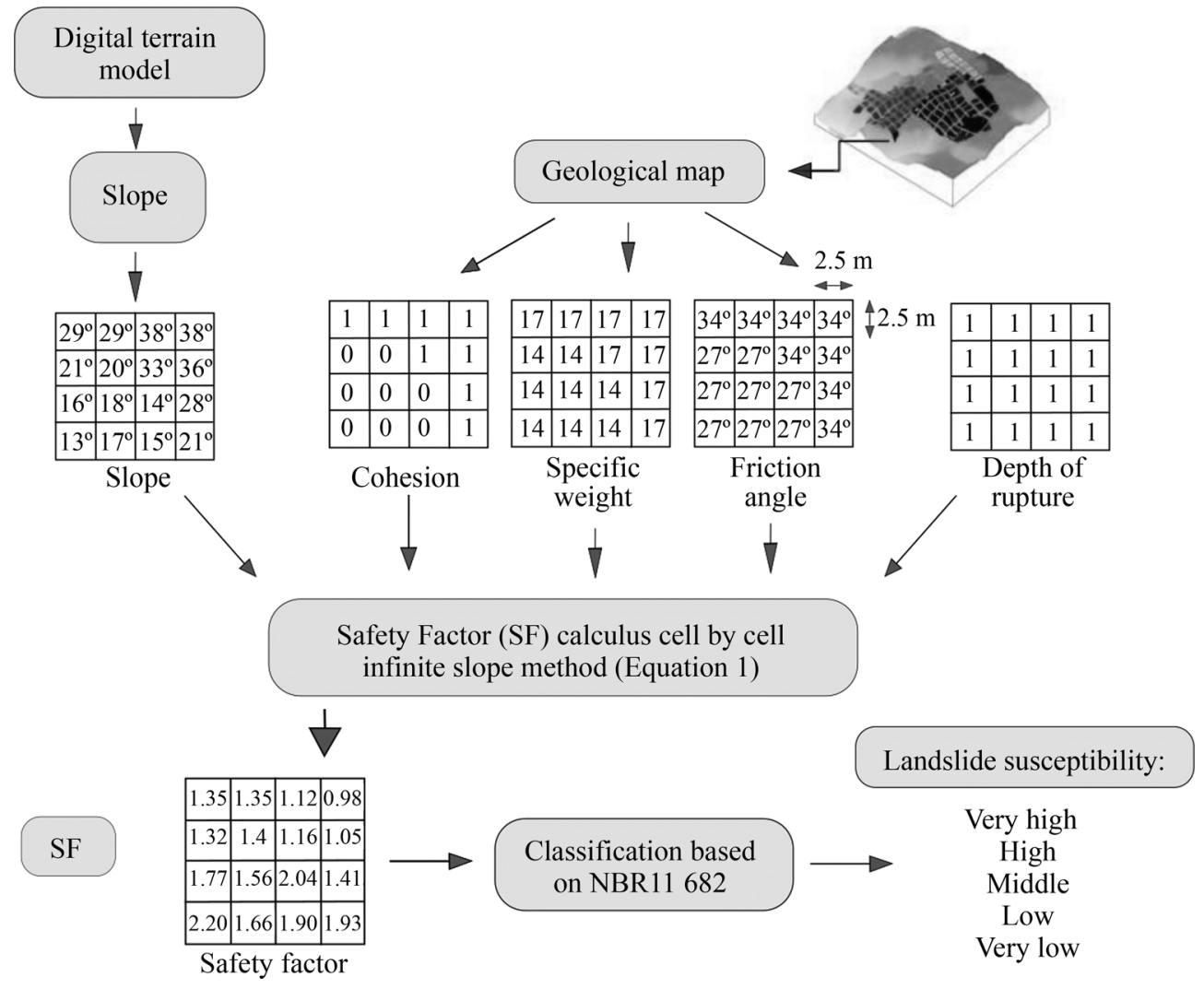

Figure 3 - Flow chart for landslide susceptibility mapping in GIS environment. 
scenario simulated were classified into five classes of susceptibility considering the minimum safety increases of 15 , 30 , and $50 \%$ for the low, medium, and high degrees of safety according NBR 11682 (ABNT, 2006) for mathematical models based on limit equilibrium (Table 1).

\subsection{Slope stability analysis at detail scale}

The detailed geological-geotechnical sections surveyed in the field were used for the slope stability analysis in this step. The stability analysis used the Bishop Simplified method (Eq. 2) and the SLOPE/W module of the GeoStudio software. The Bishop Simplified method was chosen because it provides intermediate results between the more and less conservative equilibrium methods of slope stability analysis (Krahn, 2004). The grid and radius method was used to research the critical failure surface. Four sections were selected to represent the most critical sectors and the main geological-geotechnical materials present in the highway slopes.

The geomechanical parameters used in these stability analyses were obtained from bibliography adjusted by the back analysis of landslides that occurred in the highway cuts sustained by residual soils of the three main geological formations present in the study area (Botucatu, Serra Geral and Adamantina Formations).

\subsection{Synthesis}

The results obtained in the previous steps were aggregated and analyzed resulting in the final map of landslide susceptibility in the slopes of the studied highway.

\section{Results and Analyses}

\subsection{Thematic maps and characterization of the study area}

The hypsometric map was sliced into six elevation intervals and the percentage areas of each class were calculated. The study area presents elevations ranging from 553 to $762 \mathrm{~m}$. The elevations tend to increase from northeast to southwest. About $90 \%$ and $100 \%$ of the study area presented elevations between 550 and $650 \mathrm{~m}$ and 650 and $750 \mathrm{~m}$ on sheets 1 and 7 , respectively. The elevations above $750 \mathrm{~m}$ occur only on sheets 4 and 5, comprising 3.6 and $6.2 \%$ of their total areas respectively (Table 2).

The slope map was produced at continuous intervals of degrees and was subsequently reclassified into five classes expressed as percentages and related to erosion and landslide susceptibility (Table 3 ). Table 4 presents the percentage areas of each of these five slope classes in the study area.

The slope values varied from 0.1 to $180 \%$ (0.006 to $60.9^{\circ}$ ), but there is a high predominance of slopes lower than $12 \%$ throughout the study area (about $70 \%$ of the total area in each of the seven sheets of the study area). Only the sheets 1,4 and 5 present almost $11 \%$ of their total area with slope between $20 \%$ and $50 \%$ (very high susceptibility to erosion and medium susceptibility to landslides) and only sheet 5 presents almost $5 \%$ of its total area with slope over $50 \%$ (very high susceptibility to erosion and high susceptibility to landslides, Tables 3 and 4).

Regarding the distribution of the geological formations in the study area (see Section 2), the presence of the

Table1 - Classes of safety factors $(S F)$.

\begin{tabular}{llc}
\hline$S F$ & Failure condition represented & Susceptibility \\
\hline$\leq 1$ & Failure & Very high \\
1.01 to 1.3 & $1 \%$ to $30 \%$ over the failure condition & High \\
1.31 to 1.5 & $31 \%$ to $50 \%$ over the failure condition & Middle \\
1.51 to 2 & $51 \%$ to $100 \%$ over the failure condition & Low \\
$>2$ & $100 \%$ over the failure condition & Very low \\
\hline
\end{tabular}

Table 2 - Percentage areas of hypsometric classes (source: hypsometric map).

\begin{tabular}{lccccccc}
\hline Hypsometric classes $(\mathrm{m})$ & Sheet 1 & Sheet 2 & Sheet 3 & Sheet 4 & Sheet 5 & Sheet 6 & Sheet 7 \\
\hline $534-550$ & 8.7 & 0 & 0 & 0 & 0 & 0 & 0 \\
$550-600$ & 43.4 & 7.5 & 5.5 & 3.8 & 0 & 0 & 0 \\
$600-650$ & 44.9 & 53.3 & 41.2 & 45.1 & 6.2 & 1.9 & 15.8 \\
$650-700$ & 3 & 39.2 & 53.2 & 25.9 & 22.2 & 82.3 & 78.2 \\
$700-750$ & 0 & 0 & 0 & 21.6 & 65.4 & 0 & 0 \\
$750-762$ & 0 & 0 & 0 & 3.6 & 6.2 & 0 \\
\hline
\end{tabular}


Table 3 - Slope classes (\%) and erosion and landslide susceptibility.

\begin{tabular}{lcl}
\hline \multicolumn{2}{l}{ Slope classes } & Erosion and landslide susceptibility \\
\cline { 1 - 2 }$(\%)$ & $\left({ }^{\circ}\right)$ & \\
\hline $0-6$ & $0-3.4$ & Low to erosion and very low to landslides \\
$6-12$ & $3.4-6.8$ & $\begin{array}{l}\text { Medium to erosion and very low to land- } \\
\text { slides }\end{array}$ \\
$12-20$ & $6.8-11.3$ & High to erosion and low to landslides \\
$20-50$ & $11.3-26.6$ & $\begin{array}{l}\text { Very high to erosion and medium to land- } \\
\text { slides } \\
>50\end{array}$ \\
& $>26.6$ & $\begin{array}{l}\text { Very high to erosion and high to land- } \\
\text { slides }\end{array}$ \\
\hline
\end{tabular}

Adamantina Formation is noticed in a large percentage on sheets 5, 6 and 7, and the presence of the Botucatu Formation in high percentages on sheets 2 and 3 (Table 5).

Considering the distribution of slopes by the different geological formations present in the study area, only the Serra Geral/Basic Intrusive formation has almost $15 \%$ and $4 \%$ of its total area with slopes between 20 to $50 \%$ and above $50 \%$ respectively (Table 6 ).

The field surveys registered 33 control points. These control points were characterized considering their geological-geotechnical material (rocks, residual and transported soils, landfill), features of slope instability (landslide scars and erosive processes, cracks, springs) and the presence of drainage systems and other slope containment structures.

Only a few highway cuts that expose basalts and diabase of the Serra Geral Formation presented low weath- ered rock expositions, which have the potential to trigger rock falls and boulder rolling processes. Shallow landslides scars were identified on the highway slopes with residual soils of all geological formations present in the study area. Typically, these scars affect the total height of the highway cuts, presenting few meters width (2 to $5 \mathrm{~m}$ ) and depths less than $2 \mathrm{~m}$ (Fig. 2). Features of slope instability were not identified on the highway landfills.

\subsection{Landslides susceptibility mapping applying infinite slope model}

The following three main scenarios were simulated based on the results of the thematic maps and geological-geotechnical characterization of the study area: 1 Unsatured condition and failure surface $1 \mathrm{~m}$ deep; 2 Unsatured condition and failure surface $2 \mathrm{~m}$ deep and 3 Water level $0.5 \mathrm{~m}$ above the failure surface $1 \mathrm{~m}$ deep.

The map of geological and geotechnical units guided the bibliographic search for the geomechanical parameters of the formations found in the region. Similar geomechanical parameters were used for the residual soils of the diabase and basalt (Serra Geral Formation). The minimum values for each formation of Table 7 were considered for the simulations.

During the initial simulations for the calculation of $S F$ using the infinite slope method and considering the boundary conditions described above, for slopes greater than about $60^{\circ}$, the $F S$ values began to increase rather than decrease with increasing of slope value. Specific simulations were performed to understand these anomalous results related to limitations of the infinite slope stability analysis method not mentioned in previous studies.

Table 4 - Percentage areas of slope classes by (source: slope map).

\begin{tabular}{|c|c|c|c|c|c|c|c|c|}
\hline \multicolumn{2}{|c|}{ Slope classes } & \multirow[t]{2}{*}{ Sheet 1} & \multirow[t]{2}{*}{ Sheet 2} & \multirow[t]{2}{*}{ Sheet 3} & \multirow[t]{2}{*}{ Sheet 4} & \multirow[t]{2}{*}{ Sheet 5} & \multirow[t]{2}{*}{ Sheet 6} & \multirow[t]{2}{*}{ Sheet 7} \\
\hline$(\%)$ & $\left({ }^{\circ}\right)$ & & & & & & & \\
\hline $0.1-6$ & $0-3.4$ & 15.4 & 27.1 & 67.0 & 24.9 & 41.5 & 41.3 & 51.3 \\
\hline $6-12$ & $3.4-6.8$ & 51.5 & 49.5 & 25.9 & 44.8 & 31.9 & 41.7 & 38.0 \\
\hline $12-20$ & $6.8-11.3$ & 20.5 & 20.1 & 6.0 & 15.6 & 10.7 & 11.4 & 8.6 \\
\hline $20-50$ & $11.3-26.6$ & 11.8 & 3.4 & 1.0 & 11.7 & 11.1 & 4.5 & 2.1 \\
\hline 50-180 & $26.6-60.9$ & 0.7 & 0 & 0 & 3.0 & 4.8 & 1.2 & 0.1 \\
\hline
\end{tabular}

Table 5 - Percentage areas of geological formations (source: geological units map).

\begin{tabular}{lccccccc}
\hline Geological material & Sheet 1 & Sheet 2 & Sheet 3 & Sheet 4 & Sheet 5 & Sheet 6 & Sheet 7 \\
\hline Alluvial Deposit & 3.4 & 1.8 & 0 & 0 & 0 & 0 & 0 \\
Adamantina Fm. & 0 & 0 & 0 & 11.4 & 46.3 & 72.8 & 0 \\
Basic Intrusive & 71.0 & 45.5 & 0 & 0 & 0 & 0 & 3.1 \\
Serra Geral Fm. & 0 & 0 & 0 & 55.3 & 52.4 & 0 & 0 \\
Botucatu Fm. & 25.6 & 52.7 & 100 & 33.3 & 1.4 & 0 \\
\hline
\end{tabular}


Table 6 - Percentage areas of slope classes by geological formations (source: slope and geological units maps).

\begin{tabular}{|c|c|c|c|c|c|}
\hline \multicolumn{2}{|c|}{ Slope classes } & \multicolumn{4}{|c|}{ Geological formations } \\
\hline$(\%)$ & $\left({ }^{\circ}\right)$ & Botucatu & Serra Geral/Basic Intrusive & Adamantina & Alluvial Deposit \\
\hline $0.1-6$ & $0-3.4$ & 51.0 & 15.9 & 50.3 & 66.3 \\
\hline $6-12$ & $3.4-6.8$ & 38.6 & 44.2 & 39.0 & 25.8 \\
\hline $12-20$ & $6.8-11.3$ & 8.5 & 21.6 & 8.9 & 6.1 \\
\hline $20-50$ & $11.3-26.6$ & 1.8 & 14.6 & 1.7 & 1.9 \\
\hline $50-180$ & $26.6-60.9$ & 0 & 3.7 & 0.1 & 0 \\
\hline
\end{tabular}

Table 7 - Geological and geotechnical materials and geomechanical parameters.

\begin{tabular}{|c|c|c|c|c|c|}
\hline Materials & & c' $^{\prime}(\mathrm{kPa})^{*}$ & $\Phi^{\prime}\left({ }^{\circ}\right)^{*}$ & rnat $\left(\mathrm{kN} / \mathrm{m}^{3}\right)$ & References \\
\hline Landfill & & 0 & 33.8 & 17.5 & Magnani (2006) \\
\hline Alluvial deposit & & 5 & 30 & 13.7 & \\
\hline \multirow[t]{7}{*}{ Residual soils } & Botucatu Fm. & 2 & 28 & 15.32 & \multirow{3}{*}{$\begin{array}{l}\text { Augusto Filho \& } \\
\text { Fernandes (2018) }\end{array}$} \\
\hline & & 8 & 32 & 15.32 & \\
\hline & & 5 & 30 & 15.32 & \\
\hline & \multirow[t]{3}{*}{ Serra Geral Fm. } & 13 & 31.5 & 14.9 & \multirow[t]{3}{*}{ Pinto et al. (1993) } \\
\hline & & 35 & 20 & 17.9 & \\
\hline & & 19 & 29 & 16.4 & \\
\hline & Adamantina Fm. & 20 & 38.1 & 18.25 & Queiroz (1986) \\
\hline
\end{tabular}

(*) In terms of effective stress.

These simulations considered the variation of the geomechanical parameters, the slopes, the failure surface depth and the saturation conditions. Tables 8 and 9 exemplify the results of these simulations for the residual soils of Botucatu Formation for unsaturated and saturated conditions respectively.

The results of Table 8 show that the shallower the failure surface and the greater the cohesion value of the soil, the smaller the maximum slope value that the infinite slope method will present coherent results ( $F S$ decreasing with increasing slope). The friction angle and water level height seem not to influence the slope value from which the $S F$ inversion occurs (Table 9).

By differentiating the infinite slope equation with respect to the slope angle, we can find the slope from which $S F$ inversion occurs for given values of cohesion, friction angle and failure surface depth of rupture. Equation 5 shows this process for the given parameters of Botucatu Formation $\mathbf{c}^{\prime}=8 \mathrm{kpa}, \gamma_{\text {nat }}\left(\mathrm{kN} / \mathrm{m}^{3}\right)=15,32 \mathrm{kN} / \mathrm{m}^{3}, \Phi^{\prime}=32^{\circ}$, as Fig. 4 plots the equation. Table 10 shows the results of these analyses for each of the 3 main geological formations.

$$
\begin{aligned}
& \left.S F^{\prime}=-0.018227981744066105 \operatorname{Csc}^{\circ} x\right]^{2} \\
& +0.018227981744066105 \operatorname{Sec}\left[{ }^{\circ} x\right]^{2} \\
& -{ }^{\circ} \mathrm{Cs}\left[{ }^{\circ} x\right]^{2} \tan \left[32^{\circ}\right]
\end{aligned}
$$

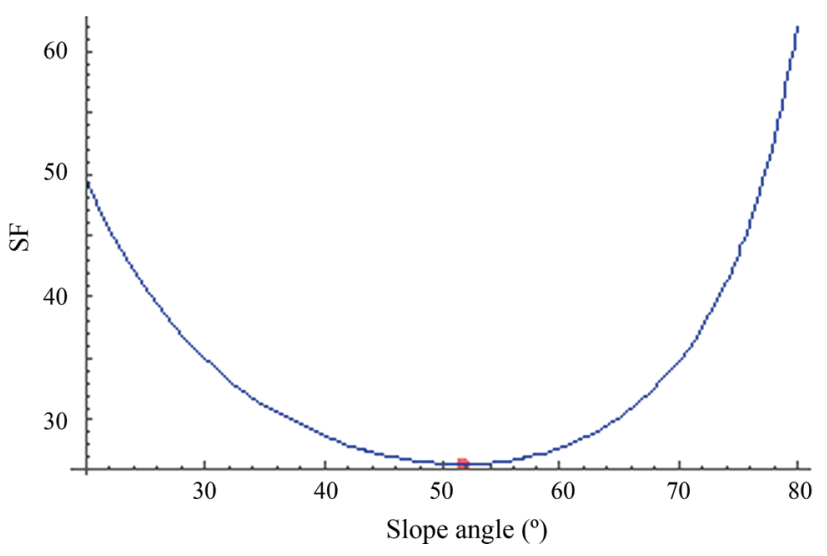

Figure 4 - Plot of Eq. 5.

After identifying the limitations of the infinite slope stability analysis method described above, the simulations were carried out to prepare the mapping of landslide susceptibility in the 1: 10,000 scale. Tables 11,12 and 13 show the percentage areas of susceptibility classes in the study area considering the scenarios 1,2 and 3 .

The three simulated scenarios confirm that the section of the highway studied is located in sites with predominantly low susceptibility to landslides, as indicated by the data collected in the inventory step. 
Table 8 - $S F$ vs. slope, depth of failure and effective cohesion (residual soils of Botucatu Fm.). Lines 3, 9 and 14 show the slopes from which inversion of Safety Factor $(S F)$ occurs.

\begin{tabular}{|c|c|c|c|c|c|c|}
\hline$I D$ & $S F$ & Slope $\left(^{\circ}\right)$ & Depth of failure surface $(\mathrm{m}) *$ & $S F$ & Slope $\left(^{\circ}\right)$ & c' $^{\prime}(\mathrm{kPa})^{*}$ \\
\hline 1 & 3.49 & 30 & \multirow[t]{5}{*}{0.5} & 3.49 & 30 & \multirow[t]{5}{*}{8} \\
\hline 2 & 2.65 & 50 & & 2.65 & 50 & \\
\hline 3 & 2.77 & 60 & & 2.77 & 60 & \\
\hline 4 & 3.48 & 70 & & 3.48 & 70 & \\
\hline 5 & 6.22 & 80 & & 6.22 & 80 & \\
\hline 6 & 2.29 & 30 & \multirow[t]{5}{*}{1} & 2.29 & 30 & \multirow[t]{5}{*}{4} \\
\hline 7 & 1.58 & 50 & & 1.58 & 50 & \\
\hline 8 & 1.57 & 60 & & 1.57 & 60 & \\
\hline 9 & 1.85 & 70 & & 1.85 & 70 & \\
\hline 10 & 3.16 & 80 & & 3.16 & 80 & \\
\hline 11 & 1.69 & 30 & \multirow[t]{5}{*}{2} & 1.69 & 30 & \multirow[t]{5}{*}{2} \\
\hline 12 & 1.05 & 50 & & 1.05 & 50 & \\
\hline 13 & 0.96 & 60 & & 0.96 & 60 & \\
\hline 14 & 1.04 & 70 & & 1.04 & 70 & \\
\hline 15 & 1.64 & 80 & & 1.64 & 80 & \\
\hline
\end{tabular}

$\left(^{*}\right) \theta^{\prime}=32^{\circ}$ was adopted for these simulations.

Table 9 - SF vs. slope, friction angle and water level (residual soils of Botucatu Fm.). Lines 3, 8 and 13 show the slopes from which inversion of Safety Factor $(S F)$ occurs.

\begin{tabular}{|c|c|c|c|c|c|c|}
\hline$I D$ & $S F$ & Slope $\left(^{\circ}\right)$ & Friction angle $\left(^{\circ}\right)$ & $S F$ & Slope $\left(^{\circ}\right)$ & Water level (m) \\
\hline 1 & 3.49 & 30 & \multirow[t]{5}{*}{32} & 1.84 & 30 & \multirow[t]{5}{*}{0.5} \\
\hline 2 & 2.65 & 50 & & 1.31 & 50 & \\
\hline 3 & 2.77 & 60 & & 1.32 & 60 & \\
\hline 4 & 3.48 & 70 & & 1.60 & 70 & \\
\hline 5 & 6.22 & 80 & & 2.78 & 80 & \\
\hline 6 & 3.22 & 30 & \multirow[t]{5}{*}{25} & 1.65 & 30 & \multirow[t]{5}{*}{0.75} \\
\hline 7 & 2.51 & 50 & & 1.20 & 50 & \\
\hline 8 & 2.68 & 60 & & 1.22 & 60 & \\
\hline 9 & 3.42 & 70 & & 1.49 & 70 & \\
\hline 10 & 6.19 & 80 & & 2.62 & 80 & \\
\hline 11 & 2.72 & 30 & \multirow[t]{5}{*}{10} & 1.48 & 30 & \multirow[t]{5}{*}{1} \\
\hline 12 & 2.27 & 50 & & 1.09 & 50 & \\
\hline 13 & 2.51 & 60 & & 1.13 & 60 & \\
\hline 14 & 3.31 & 70 & & 1.40 & 70 & \\
\hline 15 & 6.14 & 80 & & 2.47 & 80 & \\
\hline
\end{tabular}

(*) Cohesion $=8 \mathrm{KPa}$ and depth of failure surface $=0.5 \mathrm{~m}$ were adopted for these simulations.

Table 10 - Results of the analyses of the derivative of the infinite slope equation.

\begin{tabular}{lcccc}
\hline Residual soil & $\begin{array}{c}\text { Angle for safety factor } \\
\text { inversion }\left({ }^{\circ}\right)\end{array}$ & Friction angle $\left(^{\circ}\right)$ & $\begin{array}{c}\text { Cohesion }(\mathrm{kPa}) \\
\text { Depth of failure surface } \\
(\mathrm{m})\end{array}$ & $\begin{array}{c}\text { D } \\
\text { Botucatu }\end{array}$ \\
51.65 & 32 & 8 & 0.5 \\
Serra Geral/Basic Intrusive & 50.77 & 20 & 13 & 1 \\
Adamantina & 52.63 & 38.1 & 20 & 1 \\
\hline
\end{tabular}


The simulation of scenario 2 produced the highest percentage areas of medium and high susceptibility, concentrated in sheets 4 and 5, where also the highest slopes occur. Figure 5 illustrates the cartographic result for sheet 5. The increase of the failure surface depth (scenario 2) causes a significant decrease in the $S F$ values but this decrease is not so significant when the water level increases (scenario 3).

Almost $100 \%$ of the total area of Adamantina Formation, which occurs mainly in sheets 6 and 7 of the study area, presented very low susceptibility to landslides for the three scenarios simulated (Tables 14 to 16 ). These results indicate that the geomechanical parameters adopted for this formation are probably slightly above the actual values. A small landslide in the highway cut was identified in this formation in the field surveys.

Considering the data collected in the inventory step and especially in the field surveys, the landslides in the studied area should occur mainly in unsaturated conditions and be shallow (depths of 1 to $2 \mathrm{~m}$ ), according to the boundary conditions simulated in scenarios 1 and 2.

\subsection{Detail analysis of critical slopes}

Stability analysis of the geological-geotechnical sections surveyed in the field were performed using the Bishop Simplified method and the software GeoStudio ${ }^{\circledR}$ (Slope/W) in order to detail the 1:10,000 mapping, especially the highway cuts and landfills. All these stability analyses considered the unsaturated condition (without water level).

Four sections were selected to represent the most critical sectors and the main geological-geotechnical materials present in the highway slopes, being three in cuts exposing residual soils (Botucatu, Serra Geral and Adamantina formations) and one in landfill.

All sections selected in the highway cuts present landslide scars, which made possible the accomplishment of a back analysis, that was executed in the Adamantina and Serra Geral Formations (Tables 17, 18 and Fig. 6). These formations were chosen in order to obtain most coherent geomechanical parameters, since the data used in the scenarios of semi-regional landslide susceptibility map were considered high.

Table 11 - Percentage areas of the susceptibility classes for scenario 1

\begin{tabular}{lcccccccc}
\hline Susceptibility classes & $S F$ & Sheet 1 & Sheet 2 & Sheet 3 & Sheet 4 & Sheet 5 & Sheet 6 & Sheet 7 \\
\hline Very high & $<1.0$ & 0 & 0 & 0 & 0 & 0 & 0 & 0 \\
High & 1.0 to 1.3 & 0 & 0 & 0 & 0 & 0 & 0 & 0 \\
Medium & 1.3 to 1.5 & 0 & 0 & 0 & 0 & 0 & 0 & 0 \\
Low & 1.5 to 2.0 & 0.1 & 0.2 & 0.1 & 0.2 & 0.6 & 0.2 & 0 \\
Very low & $>2.0$ & 99.9 & 99.8 & 99.9 & 99.8 & 99.4 & 99.8 & 100 \\
\hline
\end{tabular}

Table 12 - Percentage areas of the susceptibility classes for scenario 2.

\begin{tabular}{lcccccccc}
\hline Susceptibility classes & $S F$ & Sheet 1 & Sheet 2 & Sheet 3 & Sheet 4 & Sheet 5 & Sheet 6 & Sheet 7 \\
\hline Very high & $<1.0$ & 0 & 0 & 0 & 0 & 0 & 0 & 0 \\
High & 1.0 a 1.3 & 0.16 & 0.02 & 0.001 & 0.28 & 1.08 & 0.33 & 0 \\
Medium & 1.3 a 1.5 & 0.29 & 0.05 & 0.012 & 1.56 & 2.02 & 0.50 & 0.005 \\
Low & 1.5 a 2.0 & 1.51 & 0.25 & 0.17 & 4.09 & 5.00 & 1.01 & 0.05 \\
Very low & $>2.0$ & 98.05 & 99.7 & 99.8 & 94.08 & 91.9 & 98.2 & 99.9 \\
\hline
\end{tabular}

Table 13 - Percentage areas of the susceptibility classes for scenario 3.

\begin{tabular}{lcccccccc}
\hline Susceptibility classes & $S F$ & Sheet 1 & Sheet 2 & Sheet 3 & Sheet 4 & Sheet 5 & Sheet 6 & Sheet 7 \\
\hline Very high & $<1.0$ & 0 & 0 & 0 & 0.005 & 0 & 0 & 0 \\
High & 1.0 to 1.3 & 0.005 & 0.08 & 0.02 & 0.05 & 0.01 & 0 & 0 \\
Medium & 1.3 to 1.5 & 0.02 & 0.11 & 0.07 & 0.04 & 0.01 & 0 & 0 \\
Low & 1.5 to 2.0 & 0.33 & 0.53 & 0.3 & 0.7 & 1.66 & 0.5 & 0 \\
Very low & $>2.0$ & 99.6 & 99.3 & 99.6 & 99.2 & 98.3 & 99.5 & 100 \\
\hline
\end{tabular}


Tables 17 and 18 show the cohesion/friction angle various combinations of cohesion and friction angle have pair chosen in each back analysis. As might be expected, FS close to 1.0. The Adamantina Formation residual soils,

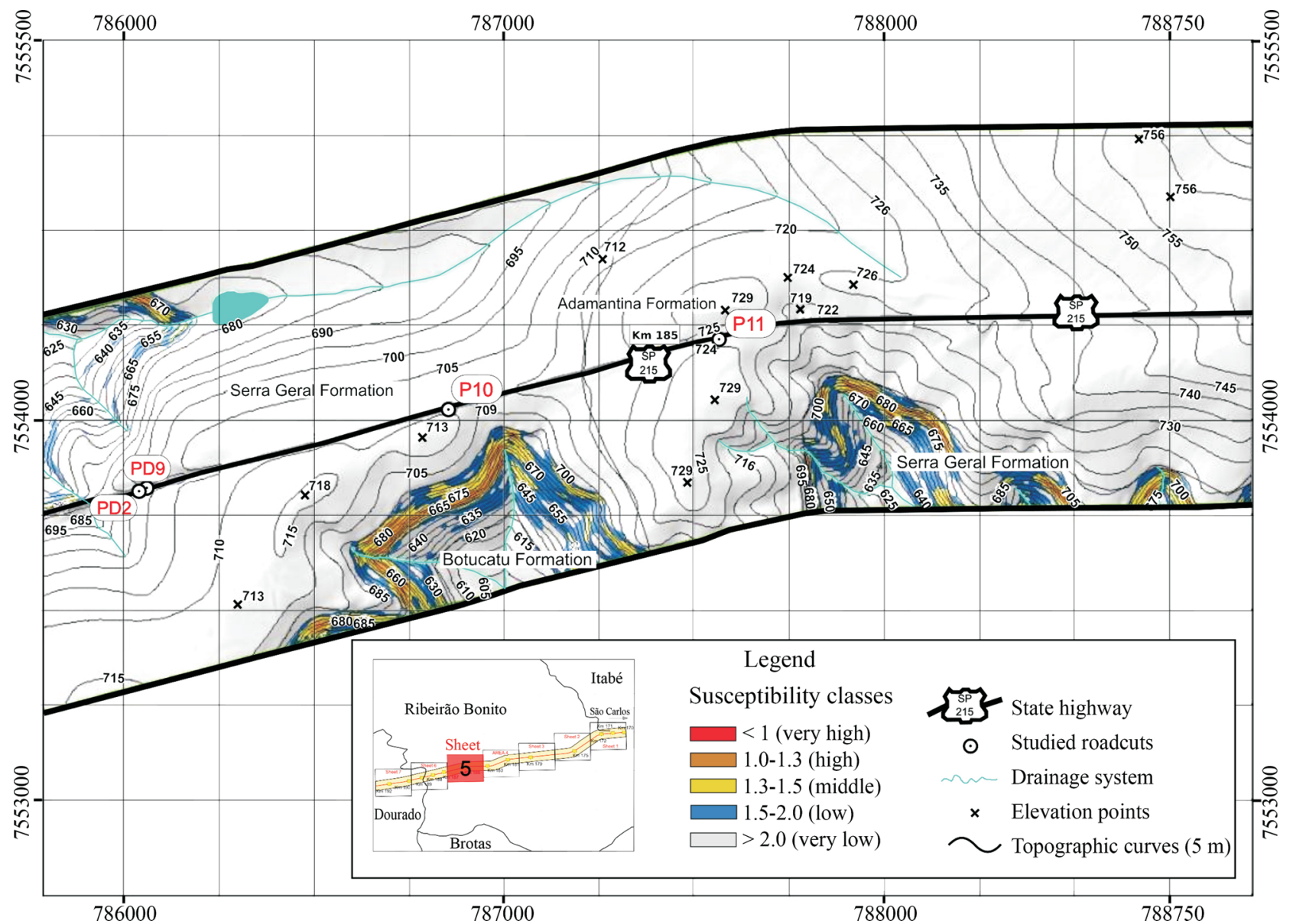

Figure 5 - Susceptibility mapping of sheet 5 considering scenario 2.

Table 14 - Percentage areas of geological materials per susceptibility classes of scenario 1.

\begin{tabular}{lccccc}
\hline Susceptibility classes & $S F$ & Botucatu & Serra Geral/Basic Intrusive & Alluvial deposit & Adamantina \\
\hline Very high & $<1.0$ & 0 & 0 & 0 & 0 \\
High & 1.0 to 1.3 & 0.001 & 0 & 0 & 0 \\
Medium & 1.3 to 1.5 & 0.02 & 0 & 0 & 0 \\
Low & 1.5 to 2.0 & 0.18 & 0.38 & 0 & 0 \\
Very low & $>2.0$ & 99.8 & 99.6 & 100 & 100 \\
\hline
\end{tabular}

Table 15 - Percentage areas of geological materials per susceptibility classes of scenario 2.

\begin{tabular}{lccccc}
\hline Susceptibility classes & $S F$ & Botucatu & Serra Geral/Basic Intrusive & Alluvial deposit & Adamantina \\
\hline Very high & $<1.0$ & 0 & 0 & 0 & 0 \\
High & 1.0 to 1.3 & 0.02 & 0.70 & 0 & 0 \\
Medium & 1.3 to 1.5 & 0.05 & 1.66 & 0 & 0 \\
Low & 1.5 to 2.0 & 0.28 & 4.38 & 0.06 & 0.01 \\
Very low & $>2.0$ & 99.7 & 93.3 & 99.94 & 99.99 \\
\hline
\end{tabular}


Table 16 - Percentage areas of geological materials per susceptibility classes of scenario 3.

\begin{tabular}{lccccc}
\hline Susceptibility classes & $S F$ & Botucatu & Serra Geral/Basic Intrusive & Alluvial deposit & Adamantina \\
\hline Very high & $<1.0$ & 0.002 & 0 & 0 & 0 \\
High & 1.0 to 1.3 & 0.08 & 0 & 0 & 0 \\
Medium & 1.3 to 1.5 & 0.12 & 0 & 0 & 0 \\
Low & 1.5 to 2.0 & 0.59 & 1.05 & 0.1 & 0 \\
Very low & $>2.0$ & 99.2 & 98.95 & 99.9 & 100 \\
\hline
\end{tabular}

although sandy, have significant percentages of fines (around $30 \%$ at least) and Serra Geral Formation soils are clayey. Thus, it was used the pair with the highest cohesion and friction value that back analysis of the landslides affecting the residual soils of these formations resulted in FS close to 1.0 .

The results clearly show that for the residual soils of Adamantina and Serra Geral Formations the values of effective friction angle and cohesion used in the semi-regional landslide susceptibility map are quite high for the reality of the site as shown by the back analysis (Tables 7, 17 and 18).

The stability analysis for the slope of Botucatu Formation using the parameters of semi-regional landslide susceptibility resulted in a $S F$ value of 1.078 (Table 7 and Fig. 7a). The better fit for the strength parameters obtained from the bibliography for Botucatu Formation residual soils is due to the fact that, in this case, the parameters were obtained from shear strength (consolidated-drained triaxial compression test under saturated and unsaturated condi-

Table 17 - Back analysis of Adamantina Formation. The values used in the new modelling are: c' $(\mathrm{kPa})=4, \Phi^{\prime}\left({ }^{\circ}\right)=24.1$ and $\mathrm{SF}=$ 1.077 .

\begin{tabular}{lcc}
\hline c' $\left.^{\prime} \mathrm{kPa}\right)$ & $\Phi^{\prime}\left({ }^{\circ}\right)$ & $S F$ \\
\hline 0 & 36.1 & 1.074 \\
0 & 34.1 & 0.997 \\
1 & 32.1 & 1.028 \\
0 & 32.1 & 0.924 \\
2 & 30.1 & 1.061 \\
3 & 28.1 & 1.097 \\
3 & 26.1 & 1.032 \\
4 & 24.1 & 1.077 \\
4 & 22.1 & 1.017 \\
5 & 20.1 & 1.068 \\
5 & 18.1 & 1.013 \\
5 & 16.1 & 0.959 \\
6 & 16.1 & 1.07 \\
6 & 14.1 & 1.019 \\
\hline
\end{tabular}

Table 18 - Back analysis of Serra Geral Formation. The values used in the new modelling are: $\mathbf{c}^{\prime}(\mathrm{kPa})=5, \Phi^{\prime}\left({ }^{\circ}\right)=14$ and $\mathrm{SF}=$ 0.959 .

\begin{tabular}{lcc}
\hline $\mathbf{c}^{\prime}(\mathrm{kPa})$ & $\Phi^{\prime}\left({ }^{\circ}\right)$ & $S F$ \\
\hline 12 & 20 & 2.044 \\
11 & 20 & 1.907 \\
10 & 20 & 1.770 \\
10 & 19 & 1.748 \\
10 & 18 & 1.727 \\
9 & 18 & 1.590 \\
8 & 17 & 1.432 \\
7 & 15 & 1.253 \\
6 & 15 & 1.116 \\
6 & 14 & 1.096 \\
5 & 14 & 0.959 \\
4 & 15 & 0.842 \\
\hline
\end{tabular}

tions) tests performed by Augusto Filho \& Fernandes (2018) using soils of the same study area.

The modeling for the landfill section resulted in a $S F$ value of 1.065 (Fig. 7b). This value indicates that the parameters used for this material were slightly low, mainly related to the value of effective cohesion, since there were no signs of instability in the highway landfills in the studied section.

The results obtained in the stability analyses in the detailed geological-geotechnical sections were considered in the elaboration of the final landslide susceptibility map of the study area.

Finally, the results of the back analysis of the Adamantina and Serra Geral formations were used to calibrate the geotechnical parameters used previously in the susceptibility mapping of scenario 1 (Tables 17 and 18).

The results of the scenario 1 mapping using the calibrated parameters are described in Table 19. As expected, although areas of very low susceptibility $(S F>2)$ still predominate, there is a significant increase in areas of medium, high and very high susceptibility in the zones in which these two formations are present. 

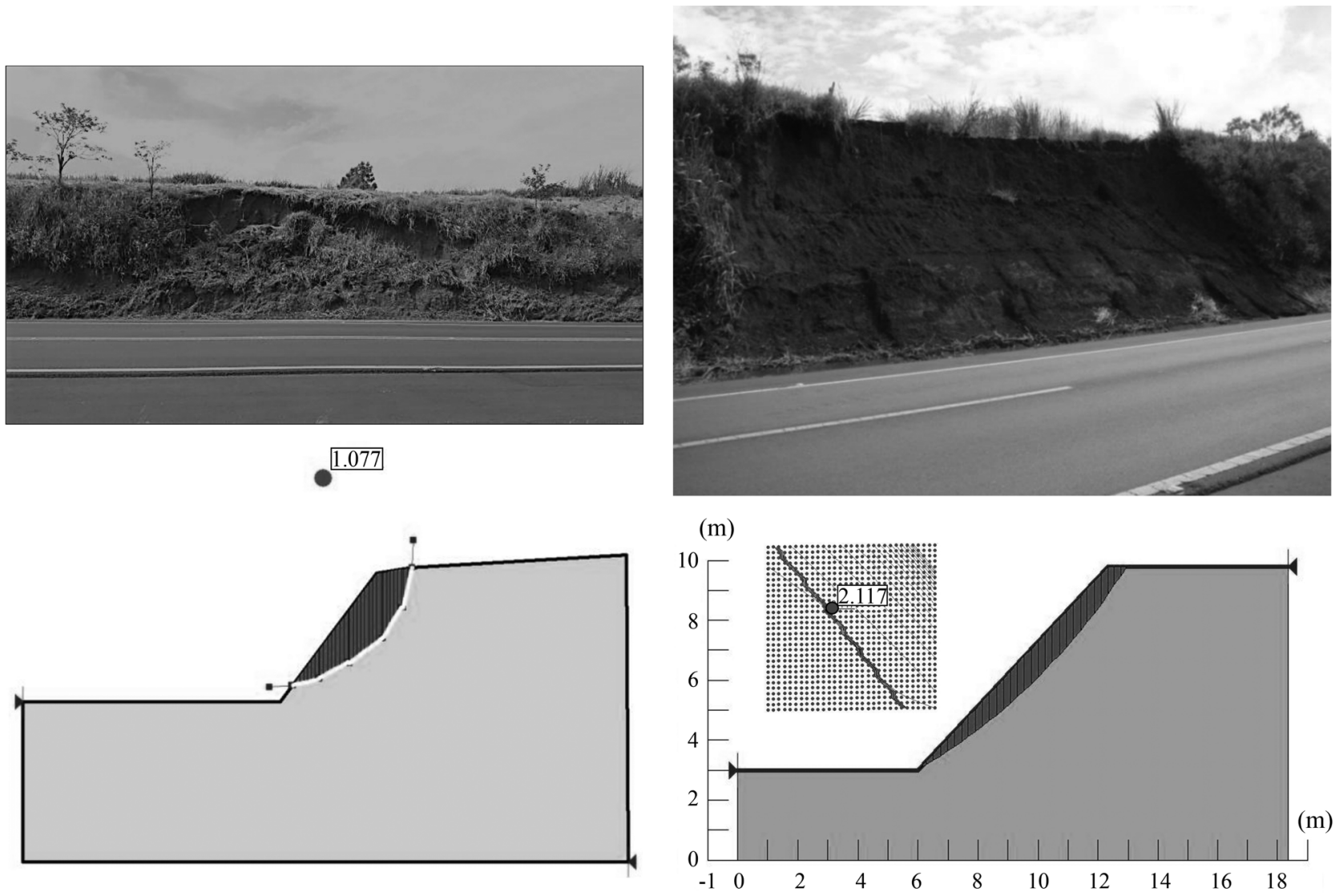

(a)

(b)

Figure 6 - Back analysis of the highway cut exposing residual soils of Adamantina (a) and slope stability analysis of Serra Geral (b) formations.

In sheet 3 , no change occurs because there is no material from Serra Geral formation / diabase. In sheet 2 only a small increase occurs in the class of low susceptibility because, despite having the basic intrusive formation, soft slopes predominate in this area (Tables 11 and 19). The results are similar for scenario 2 .

\section{Conclusions}

Stability simulations using the infinite slope method performed on the semi-detail scale (1: 10,000) allowed the identification of limitations not previously described associated with the physical-mathematical model of this method. These limitations can be overcome by calculating the angle from which $S F$ inversion occurs, obtained by means of the derivative of the equation with respect to the slope angle.

The slope stability simulations using Bishop's simplified method in detailed geological-geotechnical sections produced in the field surveys allowed the adaption of the geomechanical parameters used in the semi-regional simulations, which made the mapping of susceptibility in the study area more realistic.

The approach used was efficient even considering the limitations of the infinite slope analysis method and the

Table 19 - Percentage area of the susceptibility classes for scenario 1 with adjusted geomechanical parameters.

\begin{tabular}{lcccccccc}
\hline Susceptibility classes & $S F$ & Sheet 1 & Sheet 2 & Sheet 3 & Sheet 4 & Sheet 5 & Sheet 6 & Sheet 7 \\
\hline Very high & $<1.0$ & 0.2 & 0 & 0 & 0.6 & 1.7 & 0.5 & 0 \\
High & 1.0 to 1.3 & 0.9 & 0 & 0 & 3.6 & 4.6 & 1.0 & 0.1 \\
Medium & 1.3 to 1.5 & 1 & 0 & 0 & 2.1 & 2.4 & 0.5 & 0.1 \\
Low & 1.5 to 2.0 & 3.4 & 0.4 & 0.1 & 4.2 & 3.7 & 1.3 & 0.4 \\
Very low & $>2.0$ & 94.5 & 99.6 & 99.9 & 89.5 & 87.6 & 96.7 & 99.4 \\
\hline
\end{tabular}



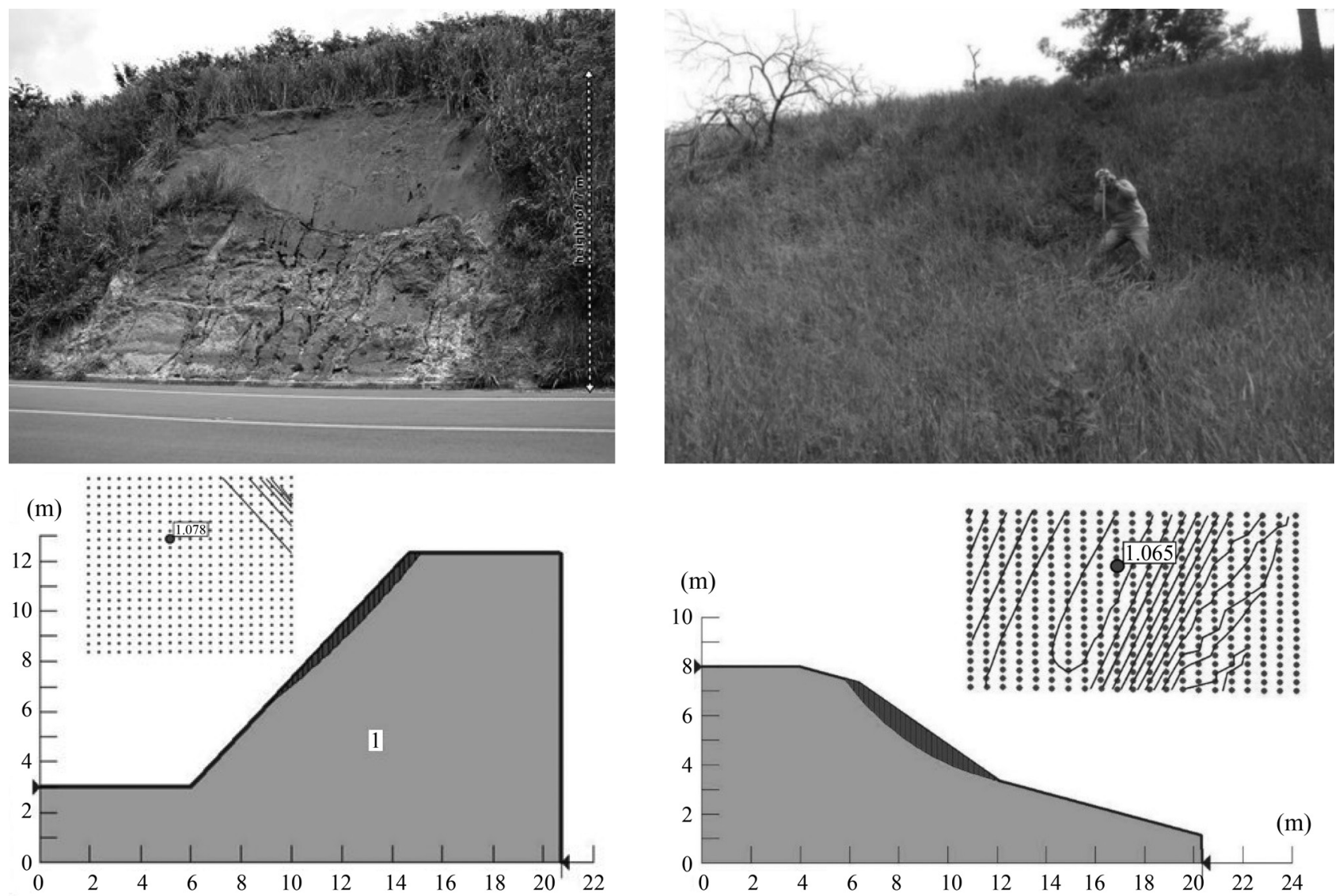

Figure 7 - a) Slope stability analysis in highway cut exposing residual soil of Botucatu Formation; b) Slope stability analysis in highway landfill (see Table 7 for geomechanical parameters used).

representativeness of the geomechanical parameters used in the stability analyses.

The slopes and marginal areas of the highway more susceptible to landslides were mapped based on quantitative models of analysis, reducing the subjectivity of the mapping. The use of deterministic stability analysis models in GIS environment and in geological-geotechnical sections results in great versatility and different scenarios can be simulated, adapting them to each situation analyzed.

\section{Acknowledgments}

The authors gratefully acknowledge the financial support of the Brazilian research funding agency CAPES (Coordenação de Aperfeiçoamento de Pessoal de Nível Superior).

\section{References}

ABNT (2006). Associação Brasileira de Normas Técnicas. NBR 11682: Estabilidade de Taludes e Encostas. Rio de Janeiro, Brazil, $33 \mathrm{p}$.

Abramson, L.W.; Lee, T.S.; Sharma, S. \& Boyce, G.M. (2002) Slope Stability and Stabilization Methods. John Wiley \& Sons, New Jersey, 649 p.
Ahrendt, A. (2005). Movimentos de Massa Gravitacionais Proposta de um Sistema de Previsão: Aplicação Urbana na Área de Campos do Jordão, SP. Ph.D. Thesis, Escola de Engenharia de São Carlos, Universidade de São Paulo, $390 \mathrm{p}$.

ARCMAP (2010). Software available for Windows. ESRI.

Augusto Filho, O. (2006). Cartas de risco de escorregamentos e planos de seguro no Brasil: Um ensaio em Caraguatatuba (SP). Geotecnia (Lisboa), 108:197-214.

Augusto Filho, O. \& Fernandes, M.A. (2018) Landslide analysis of unsaturated soil slopes based on rainfall and matric suction data. Bulletin of Engineering Geology and the Environment, 78:4167-4185.

Baum, R.L.; Savage, W.Z. \& Godt, J.W. (2002). TRIGRS A Fortran program for transient rainfall infiltration and grid-based regional slope-stability analysis. US Geological Survey Open-File Report, 424:38.

Baum, L.; Savage, W.Z. \& Godt, J.W. (2008). TRIGRS - A Fortran program for transient rainfall infiltration and grid-based regional slope-stability analysis, version 2.0, US Geological Survey Open-File Report 2008-1159, available at: http://pubs. usgs. gov/of/2008/1159 and downloaded on September $4^{\text {th }} 2018$. 
DER (2015). Departamento de Estradas de Rodagem. Volume Diário Médio das Rodovias (VDM) 2015. Available

at: http://der.sp.gov.br/website/Acessos/MalhaRodoviária / VolumeDiario/ and Accessed in November 20, 2015.

Dhakal, A.S. \& Sidle, R. (2003). Long-term modelling of landslides for different forest management practices. Earth Surface Processes and Landforms, 28(8):853868.

DNIT (2014). Departamento Nacional de Infraestrutura de Transportes. Available at: http://www.dnit.gov.br/noticias/dnit-recupera-rodovia s-federais-afetadas-por-chuvas. 011 and Accessed in July 14, 2014.

Fiori, A.P. \& Carmignani, L. (2009). Fundamentos de Mecânica dos Solos e das Rochas. $2^{a}$ ed. Editora UFPR, Curitiba, 602 p.

Gaioto, N. (1992). Estabilidade de Taludes. Departamento de Geotecnia, Seção de Publicação da EESC-USP. [S.I:s.n].

GEOSTUDIO (2012). Software for Windows, GEOSLOPE INTERNATIONAL, available at http://www.geo-slope.com/support/downloads/2012 and downloaded on July $3^{\text {rd }} 2018$.

Gioia, E.; Speranza, G.; Ferretti, M.; Godt, J.W.; Baum, R.L. \& Marincioni, F. (2014). Using the TRIGRS model to predict rainfall-induced shallow landslides over large areas. EGU General Assembly Conference Abstract, v. 16, EGU2014-14134

IPT, Instituto de Pesquisas Tecnológicas do Estado de São Paulo (1981a). Mapa Geológico do Estado de São Paulo, Escala 1:500.000. 2 v. São Paulo. Publicação IPT 1184.

IPT Instituto de Pesquisas Tecnológicas do Estado de São Paulo (1981b). Mapa Geomorfológico do Estado de São Paulo, Escala 1:1.000.000. 2 v. São Paulo. Publicação IPT 1185.

Krahn, J. (2004). Stability Modeling with SLOPE/W an Engineering Methodology. First edition. GEO-SLOPE/W International Ltd., Calgary, 396 p.

Magnani, H.O. (2006). Comportamento de Aterros Reforçados Sobre Solos Moles Levados à Ruptura. Ph.D. Thesis, COPPE, UFRJ, 507 p.

Massad, F. (2003). Obras de Terra: Curso Básico de Geotecnia. Oficina de Textos, São Paulo, 170 p.

Montgomery, D.R. \& Dietrich, W.E. (1994). A physically based model for the topographic control on shallow landsliding. Water Resources Research, 30(4):1153-1171.

OFFICE (2010). Software for Windows. Microsoft.

Pack, R.T.; Tarboton, D.G. \& Goodwin, C.N. (1998). The SINMAP approach to terrain stability mapping. In: 8th Congress of the International Association of Engineering Geology. Vancouver, British Columbia, v. 21, pp. 25.
Pack, R.T.; Tarboton, D.G.; Goodwin, C.N. \& Prasad, A. (2005). SINMAP 2. A Stability Index Approach to Terrain Stability Hazard Mapping. Technical Description and Users Guide for Version 2. Canadian Forest Products Ltd, Utah, pp. 73.

Park, D.W.; Nikhil, N.V. \& Lee, S.R. (2013). Landslide and debris flow susceptibility zonation using TRIGRS for the 2011 Seoul landslide event. Natural Hazards and Earth System Sciences, 13:2833-2849.

Pinto, C.S.; Gobara, W.; Peres, J.E.E. \& Nader, J.J. (1993). Propriedades dos Solos Residuais. Solos do Interior de São Paulo. ABMS-NRSP, Depto. Geotecnia da EESCUSP, pp. 95-142.

Queiroz, R.C. (1986). Aplicação do Método de Retroanálise no Estudo da Estabilidade de Taludes de Estradas Situadas em Solos Oriundos da Formação Adamantina. Master Thesis, Escola de Engenharia de São Carlos, São Carlos, 98 p.

Ramos, V.A.; Guimarães, R.F.; Redivo, A.L.; Gomes, R.A.T.; Fernandes, N.F. \& Carvalho júnior, O.A. (2002). Aplicação do modelo SHALSTAB, em ambiente Arcview, para o mapeamento de áreas suscetíveis a escorregamento raso na região do Quadrilátero ferrífero (MG). Espaço \& Geografia, 5(1):49-67.

Rosniecek, A. \& Imai, H.N. (2013). Mapeamento Geotécnico e Análise de Áreas Suscetíveis a Deslizamentos Rasos da Bacia do Rio Ratones - Aplicação do Modelo SHALSTAB. Conclusion of Course Work, Universidade Federal de Santa Catarina, Florianópolis, 155 p.

Savage, W.Z.; Godt, J.W. \& Baum, R.L. (2004). Modeling time-dependent areal slope stability. In: Landslide: Evaluation and Stabilization. Balkema, Taylor and Francis Group, London, pp. 23-38.

Silveira, C.T.; Fiori, A.P.; Ferreira, A.M.; Felipe, R.S.; Kepel Filho, J.L.; Folador, R.M. \& Costa, L.C. (2012). Análise do fator de segurança na estabilidade das vertentes na Bacia do Rio Jacareí, Serra do Mar Paranaense. Revista Brasileira de Geomorfologia, 13(3):287297.

Skempton, A.W. \& DeLory, F.A. (1957). Stability of natural slopes in London clay. Proc. 4th Int. Conf. On Soil Mechanics and Foundation Engineering, London, v. 2, pp. 378-381.

Vieira, B.C. (2007). Previsão de Escorregamentos Translacionais Rasos na Serra do Mar (SP) a Partir de Modelos Matemáticos em Bases Físicas. Ph.D. Thesis, Instituto de Geociências, Universidade Federal do Rio de Janeiro, Rio de Janeiro, 194 p.

Wu, T.H. \& Abdel-Latif, M.A. (2000). Prediction and mapping of landslide hazard. Canadian Geotechnical Journal, 37(4):781-795.

Wu, W. \& Sidle, R.C. (1995). A distributed slope stability model for steep forested basins. Water Resources Research, 31(8):2097-2110. 